\section{Speech Act Use in Parenting Style toward Children Self-Esteem in Bad Moms Movie}

\author{
1 Wenny Pratiwi \\ 2 Malikatul Laila
}

12 Universitas Muhammadiyah Surakarta, Indonesia

\section{Abstract}

The parents become one of the crucial factors in determining children's character. Their character is influenced by the people around them who have frequently made interaction. Based on Bad Moms movie, the changes of parent's treatment to their children give an effect in several aspects. The technique of collecting the data is watching and examining the movie which relates to language use in parenting style towards children's self-esteem. The technique of data analysis was done using descriptive method speech acts theory by Kreidler (1998), parenting style theory by Baumrind (1967) and Maslow's hierarchy of needs in Shintya (2013). Based on Bad Moms movie, the use of directive utterances in the authoritative parenting style support the hearer to do something, by doing something, the children become independent. The use of directive utterances helps the hearer to reduce miscommunication and improve the effective communication.

\section{Keywords}

Speech Acts

Parenting style

Self-esteem

Bad Moms Movie

\section{Ethical Lingua}

Vol. 7, No. 2, 2020

ISSN 2355-3448 (Print)

ISSN 2540-9190 (Online)

Corresponding Email

Wenny Pratiwi

wennypratiwi962@gmail.com

Article's History

Submitted 22 July 2020

Revised 6 August 2020

Revised 25 September 2020

Accepted 25 September 2020

DOI

10.30605/25409190.195

Copyright (๑) 2019

The Author(s)

This article is licensed under CC BY-NC-SA 4.0 License

\section{(c) EY-NC-SA}




\section{Speech Act Use in Parenting Style toward Children Self-Esteem in Bad Moms Movie}

Children's character is much influenced by parenting style. In improving children's character, the environment has a significant role in determining what attitude they will have. The parents become one of the crucial factors in determining it. Confucius (1979) stated that parents have the responsibilities to their children. He stated that parents to be authority in treating the children, to manage family assets and deliver resources, to improve social status of the family, to govern and manage children's behavior, to ensure that children follow the norms of social morality and to establish children's obligations towards the family. As stated by Nugroho (2019) Indonesia is a country with a difference in many aspects. It has difference in religion, belief, ethnicity, race, culture, and tradition. Those differences make a variety character of Indonesian people. The problem of young Indonesian teachers nowadays is facing variety students, especially in their character. Their attitude is influenced by the people around them who have frequently made interaction.

According to Baumrind (1967), the parenting style divided into 3 types. They are authoritative, authoritarian and permissive. The authoritative is a type of parents who have high expectations for achievement, but they are responsive. These parents set rules and enforce boundaries by having open discussion and using reasoning. The authoritarian is a type of parents who demand high standard, usually parents are strict, discipline, and often giving a punishment to control children's behavior. The last is permissive. In this type, the parents set very few rules and boundaries and they are reluctant to enforce rules. These parents are warm but they do not like to say no or disappoint their children.

The parenting style can give any impacts to the children's character. Self-esteem encompasses all these characteristics. But it is most importantly a personal judgment of self and sense of worth primarily based upon externally compulsory criteria. They are 5 stages of Hierarchy of Needs by Maslow. In the first stage, there is self-actualization, this stage demands to be acknowledged as the best. Second, esteem needs, it is about esteem for oneself. It can be needed respect, status, self-esteem, freedom, mastery, independence. Belonging needs and love need is in the lower stage. Then, it is followed by safety needs. The last is psychological needs. Maslow divided need for self-esteem into two categories. First, it is internal respond against them dealing with getting competence, self-confident, adequacy, autonomy, independence, freedom. Therefore, individuals are sure that they have self-esteem and are able to cope with obstacles in life. Second is achievement. In this case, individuals need appreciations over what they to do.

The language use in parenting style reflected in Bad Moms movie has various ways. The various ways in uttering a language emerge different meaning based on the speaker. The language use in parenting style reflected in Bad Moms movie has significance to be exposed because of its impact to the children's attitude. The speaker purposes can be classified into seven speech acts. Kreidler (1998) differ the speaker intention into assertive utterances, performative utterances, verdictive uterances. Expressive utterances, directive utterances, commissive utterances and phatic utterances.

Assertive utterance is the speaker used language to tell what they know and what they believe. The purpose of it is to tell the information about the fact. Performative utterance is uttered by someone who has a power which make any changes in the real world. The next 
type is verdictive utterance. It is the type of speaker making assessment or judgement about the acts of others. Then in the expressive utterance, the speaker is involved. The speaker tells about what they feel. Usually, it comes or affected by the previous acts. Directive utterance is the speaker tries to get the hearer perform some acts. Commissive utterance is the speaker commits to perform some acts in the future. The last is phatic utterance. Phatic is a formulated utterance such as greetings, farewell and formula of "How are you?".

The parents do have important roles in identifying children's talent and guiding them. Mutual understanding and close relationship between the parents and children are recommended. Bad Moms Movie is the popular movie in 2016. Here, it tells about the struggle of mothers who try to make a living for her family and make her children happy. At the first time, moms treat the children as what the school principle wants. This impacts to the children' selfesteem in solving their own problem. Lately, they change the way they treat their children and it makes changes in the children's attitude. So this study shows that there is an attitude change happened to the students after the moms have treated the children based on the school principle wants.

There have been studies which relate to the object of the study. There are several researches have been done about the Bad Moms movie. (Permatasari, 2017) wrote a research A Socio-pragmatic Analysis of Women Expressive Utterances in Bad Moms Movie. The result of the research showed there are 15 types of expressive utterance intention used by women in Bad Moms movie. The dominant type of expressive utterance is expressing displeasure. In the politeness strategy, the dominant strategy uttered by the women is bald on record strategy. Putri (2017) has done research entitled The Analysis of Gender Stereotypes in Bad Moms Movie. It analyses the gender stereotypes reflected in Bad Moms movie. She used theory of Beasley. The result showed that there are 10 data of feminity, 2 data of masculinity, and 2 data of androginy. The analysis of Bad Moms movie was conducted by Sindy Agusrini (2017) in her research paper Representasi Peran Amy Sebagai Ibu Mandiri dalam Film Bad Moms 2016. The objective of the research is to represent the main actor as an independent woman. The result showed that the main character is the representative of the new female who are independent and it relates to the concept of new female individualism. The concept of it influences the the way parent, a single parent, treats her children.

The parenting style which chosen by the parents gives impact to the children's self-esteem. the research from Farzand, Çerkez, \& Çavusoglun (2017), Hesari \& Hejazi (2011), and Theresya, Latifah, \& Hernawati (2018) showed that the type of parenting which gives the most positive impact is the authoritative style. The research has been proved using qualitative and quantitative methods. The parenting style not only can be seen by its attitude but also by its language use.

In the language use analysis, especially in the speech acts, there are several researches have been done. Paper Speech Acts in Professional Maritim Discourse: A Pragmatic Risk Analysis of Bridge Team Communication Directives and Commissives in Full-Mission Simulation has been analyzed by John, Brooks, \& Schriever (2019). It focused in the use of commissive and directive utterances which gave an impact and emerged a risk in the speaker and hearer action. The result of the research contributed to evaluate causal factors in effective communication and minimize the factors of miscommunication in the maritime 
domain. The commissive and directive utterances categorized into no risk, residual risk and caused high risk.

Georgalidou (2008) studied The Contextual Parameters of Linguistic Choice: Greek Children's Preferences for the Formation of Directive Speech Acts. It investigated the children language use in directive utterance which is used to the teachers or the other students. The children tend to use declarative in directive illocutionary force. Kochańska (2018) also studied about The Hurting and Healing Power of Words (and Grammatical Construction) A Cognitive Grammar Study of the Interactive and Interpersonal Effects of a Directive Construction in Polish. It analyzed the effect of a particular directive construction. The result showed directive utterances bring about diverse pragmatic effect in different circumtances.

The analysing of language use in parenting style based on the movie which change the children's attitude is not conducted yet. Then, the research about language use in style of parenting reflected in Bad Moms movie become the newest topic to discuss and to explore. Based on Bad Moms movie, there is a different speech acts used by the parents in treating the children. The different language use in different parenting style especially in the children's attitude change, attract the researchers to describe the kind of speech acts used in the dialog of parents and children. Based on the movie, the children showed the opposite attitude in their self-esteem after having different treatment. Thus, the writers want to describe the language used especially based on the speaker intentions in both of treatments using speech acts theory by Kreidler (1998) which show its function in the parenting style.

\section{Method}

This research is a qualitative paper, based on data in the form of text and Figure (Creswell, 2019). There are two types of the data. The primary data consisting the text of the movie which relates to the topic. In this case, the text was taken from the dialog of Moms and the children in showing their self-esteem. The second data is the data cover which support the analysis. The technique of collecting data is as follows watching and examining the movie which relates to language use in parenting style towards children's self-esteem. The writers divided the dialog of the script which reflected parenting style toward children's self-esteem between Ammy as mother and her two Children Dylan and Jane. The data selected which is suitable to the topic were presented for analysis. The secondary data were collected from several previous studies which support the language use. The technique of data analysis was done using descriptive method in language use speech act by Kreidler (1998) in parenting style theory by Diana Baumrind and Maslow's hierarchy of needs.

\section{Results}

There are following the result of speech act use in showing the parenting style which had been done focusing on the impact of children's self-esteem.

\section{The activities which mothers do}

The following is the expression of Amy about her activities.

Amy: "My days are filled with dropping the kids at school, then racing to work where I have meeting. Most days I race back to school for the kid's plays, poetry readings and class project. 
Then, there is PTA meetings and volunteering and parent-teacher conferences. Then I shuttle kids to piano lessons and soccer games and dance classes and doctors' appointments."

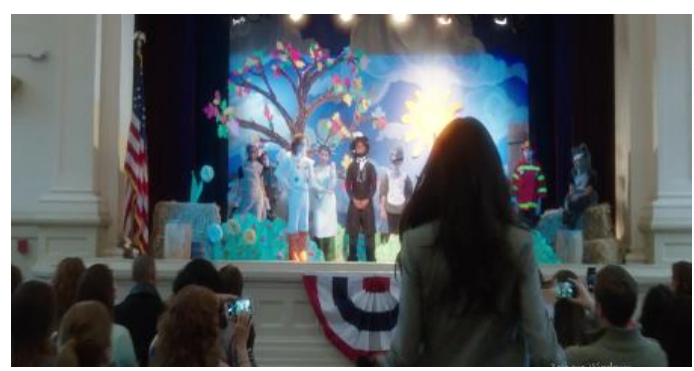

Figure 1. Amy attended Kid's play

\section{Amy treats her children}

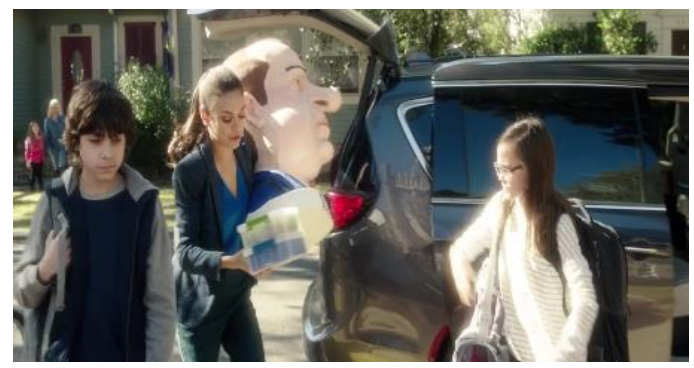

Figure 2. Amy makes breakfast and lunch and also does her son's assignment

Here is the Amy's dialog when taking the children to the school

Amy: "Here, baby. There is your organic turkey club sandwich, and Dylan, here is your peanut-free peanut butter for lunch. Baby, here is your American history project I made you. I hope you like it."

The italic sentence based on Speech act theory of Kreidler (1998), belongs to the commissive utterance. The mother showed the project that she made and she wants her son acknowledge that he likes the project. It is showing the need of acknowledgement. Here the mom implies future act by saying "i hope you like it", it means that the mom wants the children's appreciation later after showing what the mom has done for them.

The next dialog happens when they have dinner together.

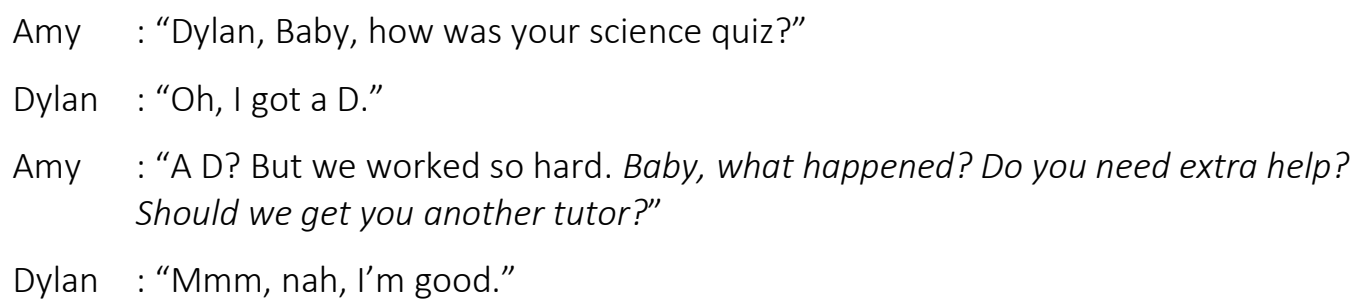

In this dialog, the question of Amy to her son showed an expressive utterance. It expressed a sympathy about what Dylan had experienced. The words "But we worked so hard" here shows that Amy feels like their effort doesn't mean anything. It indicates Amy already helped Dylan before. The sympathy here shows that it is better to get the other tutor for Dylan for the next. 
Ammy : "Jane, Oh, My Gosh! Wait! How was your soccer tryouts?"

Jane : "Coach is posting a list of who made the team tonight at 9. And I am so nervous.

Ammy : "Baby, it's okay, relax. You will make the soccer team. I promise. Just don't freak out.

Ammy's utterance showed commisive utterance. She promises her daughter to get what she wants happen. Promise here indicates that the mom wanna make her child to be relax and calm in facing what will happen then.

After a minute...

Jane : "Oh My God. I made the team. I made the team."

Ammy : "I am so relieved. Thank you. Oh My God. Baby, I am so proud of you!"

Jane : : "I am so excited. Oh My God. This is gonna look awesome on my college applications.

Ammy : "Baby, it's great. It's great. But just remember you're only 12 , so it's ..."

Jane : "Wait, what if I don't play? What if I am a loser benchwarmer scrub?"

Ammy : "You're great, you're gonna be fine, you're..."

Jane : "No, it's not fine, Mom. Do you understand how hard it is to get into an Ivy League school now? I mean, they turn away Asians."

Ammy : "That's little bit racist, but..."

Jane : “Oh, My God! I need to practice my footwork. Why'd you let me eat dessert? Oh, I know, because you hate me!"

The two utterances of Ammy in the former showed an expressive utterance. It is expressed to praise her daughter and to express her feeling too that she is happy with what her child gets. Then, the word of "you're gonna be fine" in the continuous dialog belongs to the commisive utterance which shows the commitment of the mother to make her daughter fine later.

\section{Amy expresses her feeling about her activities}

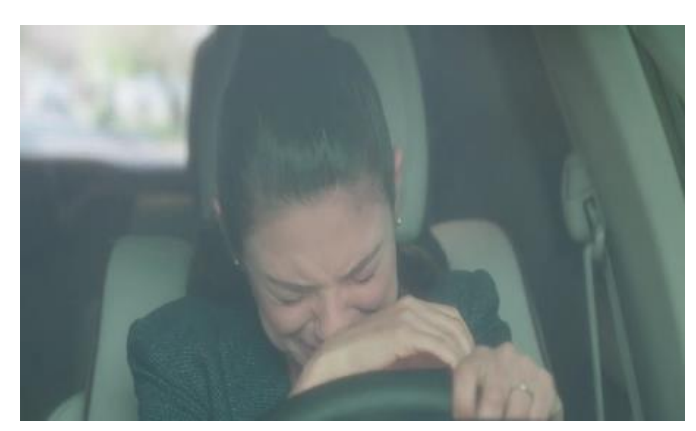

Figure 3. Amy cries in the car

Amy expresses her feeling about activities that she should be done.

Amy: "At least once a day, I feel like the worst mom in the world, and I cry in my car." 
The bake sale

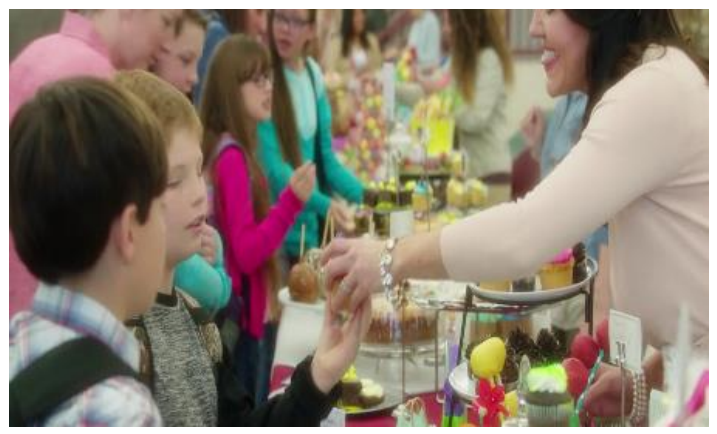

Figure 4. The activities of bake sale in the school

Here is the speech of President of PTA, Gwendolyn, about the rules of Bake sale

Gwen: "Now, I called emergency PTA meeting to address an issue that radically affects the safety of our children. The bake sale. Now, this is a list of the toxic ingredients that are absolutely banned from bake sale. No BPA, no MSG, no BHA, no BHT. Plus no soy, no sesame, and of course, no nuts, or eggs or milk or butter or salt or sugar or wheat. A special bake sale police force that will monitor the food. That will destroy any offensive treats and prosecute the wrongdoers."

\section{Mom treats the children to be independent}

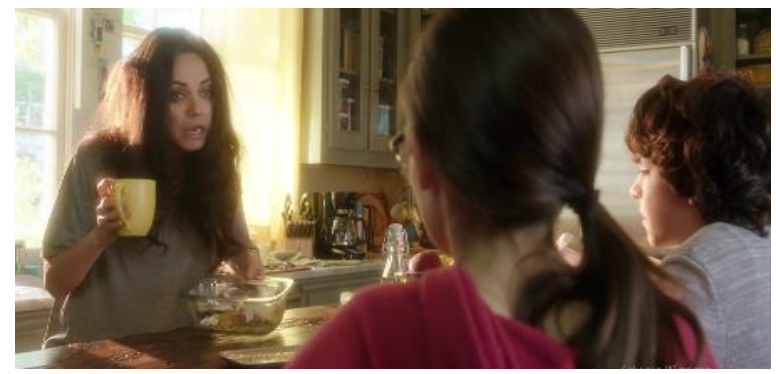

Figure 5. The children are asked to make breakfast by themselves.

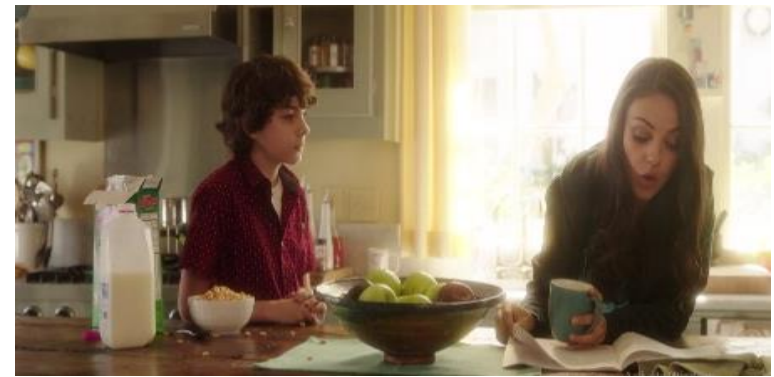

Figure 6 . The son is asked to do the homework by his self.

The following is the dialog between the children and Amy.

Dylan : "Aren't you gonna make us breakfast?

Amy: "Oh.. No."

Dylan: "But what are we gonna eat?"

Amy: "You guys are really smart. You can make your own breakfast" 
The dialog uttered by Ammy above showed an interrogative sentence but it has a meaning as a suggesstion to command her son to make some food by himself. It is supported by previous uttarance "You guys are really smart" it means that Amy encourages them to make breakfast. It belongs to the directive utterance.

After a long time..

Dylan is asking about his assignment.

Dylan : "I can't believe you're making me cook my own breakfast every single day"

Amy: "You're doing awesome, Buddy. You really are."

Dylan : “Hey, so where's my science project?

Amy: "Oh, I didn't do it. So will you please, please just do your own homework?"

The italic and bold utterance above showed a directive utterence in an interrogative form. It has a meaning to command Dylan to do his own homework.

\section{Children change the attitude}

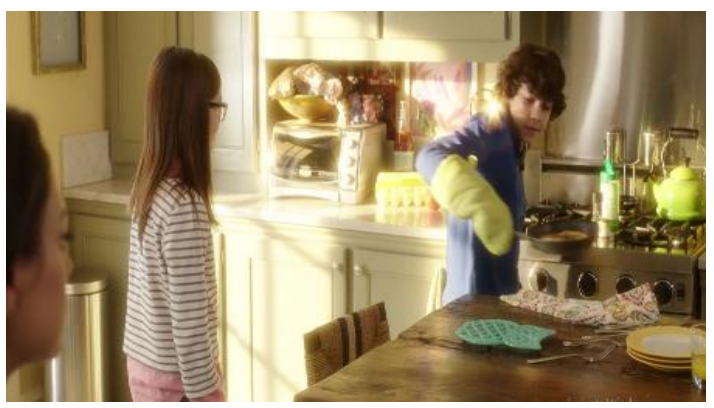

Figure 7. Dylan cooks his own cook and does his own homework

The dialog of Dylan, Jane and Mom is following here.
Ammy: "Hey, guys. Can i talk to you for a second? Look, I just wanna say l'm really sorry for how l've been acting lately."
Jane : :And I'm sorry for acting so crazy about the whole soccer thing. I'm really trying to chil out more. I mean, it's just soccer. Right?"
Dylan: "I made a frittata. You said you weren't gonna cook for us anymore, so I taught myself how to cook."
Amy: "Oh, honey. I'm so proud of you! Get in here. I love you."
Dylan : "All right, okay. Let go. Okay, I gotta go do my homework."

\section{Discussion}

In Bad Moms movie, the mothers are represented in many roles. Amy is a mother of two children. She becomes a single parent. There are many activities should be done by the mothers. The data finding has showed the activities that Amy did. She is working, dropping the kids at school, attending for the kid's plays, poetry readings and class project in the school. Then, for supported activities, there is PTA meetings and volunteering and parentteacher conferences. In there, they will discuss about the rules, the agendas that they will 
do towards the children. Then in extracurricular activities, she shuttles kids to piano lessons and soccer games and dance classes and doctors' appointments.

In the Figure 2, it showed that Amy prepares the breakfast and lunch for the children. Not only preparing the food, but also she prepares his son's homework. That is American history project. According to Baumrind (1967) the parenting style that Amy applied towards her children belongs to permissive style. As stated as Baumrind (1967), the permissive style is parents who set very few rules and boundaries and they are reluctant to enforce rules. In this case, Amy as the parent is very warm, she does not like to say no or disappoint their children. So, she is in busy preparing the children's meal while the children are only looking at their mom and watching the food is ready to serve. She also did not set any rules about her son's homework. The homework should be done by Dylan itself, instead of his mother who made it. In this scene, children's meals and homework are done by mother. The reason why mother did the homework will be clearly seen in the figure 5 and figure 6 . The children stated that they are afraid and not confident in doing the homework by themselves. It shows the children have low self-esteem. As explained in the Maslow's hierarchy of needs, that self-esteem is a need to be independence, respect, mastery and freedom. In this case, the children are not independence and cannot be freedom in doing something. They count on the duties to their mother.

The language use in permissive parenting style reflected in the dialog Amy is mostly expressive and commisive utterance. Amy said to the children "Baby, here is your American history project I made you. I hope you like it.".Based on Kreidler (1998), the utterance of Amy when giving her son's homework and breakfast belongs to the commisive utterance. The commisive utterance showed that the mother needs acknowledgement from the Dylan that he likes the project of American history that she made. Then, when Amy asked her son about his performance in the science quiz, Dylan answer he got D. Amy responded "A D? But we worked so hard. Baby, what happened? Do you need extra help? Should we get you another tutor?". The utterance belongs to the expressive utterance in expressing sympathy. The use of expression utterance in permissive parenting style make the children do not have any responsibilities of their own job. And in dialog between Ammy and Jane about the announcement, Ammy used expressive utterance "You're great. I am so proud of you." It belongs to the expressive utterance in praising and expressing proud. In this dialog Ammy also used commissive utterance to calm down her daughter "You will make the soccer team. I promise." The speaker commits to the future action to make Jane in the soccer team.

Those activities made Amy frustrated. Based on the Figure 3, she cries once a day in the car to express how tired she is. Besides doing her daily activities, there is an issue that comes up radically affects the safety of the children, based on the President of PTA. Based on that issue, Gwendolyn, who has a power to set the rules in the school, initiates the bake sale. The bake sale has a purpose to make the parents aware about the ingredients that they used for children's daily meals. She announced a list of the toxic ingredients that are absolutely banned from bake sale. It is said that no BPA, no MSG, no BHA, no BHT plus no soy, no sesame, no nuts, or eggs or milk or butter or salt or sugar or wheat. There is a lot of lists. Then, she appointed Amy as a special bake sale police force that will monitor the food. That will destroy any offensive treats and prosecute the wrongdoers. Amy who had a bad day, realize that something happened to her right now is a real thing than the issue which brought by Gwendolyn. 
After realizing that trying to be the perfect mom is killing herself as stated in the dialog when she is with her friends. She stated that "it makes them insane. In this day and age, it is impossible to be a good mom." The meaning of this day and age reflected on the children character's nowadays. In the beginning, she used parenting style of permissive, now she changed her parenting style. The changing of parenting style of Amy can be seen in the Figure 5 and 6 . Amy asked her children to make a food and homework by themselves. At the first time the children being asked to do anything individually, they have low self-esteem in doing those. The self-esteem which is aimed in this paper is the independency. The thought of self-esteem was taken by Maslow's hierarchy of needs. It is said that esteem need is esteem for oneself, it consists of dignity, independency, achievement. Dylan is worried about his homework, because he thinks that he is slow learner. So he does not want to try it first. It can be classified as the effect of permissive parenting style of Amy who gives everything that he needs and never let him try to be independent son.

The language use in the authoritative parenting style is directive utterance. It reflected in the dialog when Amy asked the children to make their own breakfast. She said "You guys are really smart. You can make your own breakfast". It is stated not as an imperative sentence but the speaker has intention to make children serve their own breakfast. The utterance in implementing authoritative parenting style emerges in the dialog when Dylan asked his mother to do his homework. Amy answered "Oh, I didn't do it. So will you please, please just do your own homework?". The form of sentence is interrogative but pragmatic meaning from the utterance is asking her son to do the homework by himself. In the authoritative parenting style, the mother used directive utterance in making the children to do something to be independent children.

Based on the movie, Amy has changed from permissive parenting style into authoritative parenting style. Baumrind (1967) stated that authoritative is a type of parents who have high expectations for achievement, but they are responsive. These parents set rules and enforce boundaries by having open discussion and using reasoning. In asking her children to do anything by themselves is not directly commanded by Amy, but it has been discussed before with Dylan. Amy said in the dialog "you are gonna actually have to start doing your own homework from now on. You're not a slow learner. You're just entitled. It means that Mommy and Daddy have been spoiling you and now you think the world owes you something, but it doesn't. If you don't learn how to work hard now, then you're just gonna grow up to be like another entitled white dude who thinks he's awesome for no reason. And then you'll start a ska band, and it'll be awful, and you'll be mean to girls to look interesting but you won't actually be interesting. I'm not okay with that, so please, just do your own homework." By giving the explanation why Dylan should have self-esteem in independence, he agreed to do what mother said. It belongs to authoritative parenting style because it involves the two side agreement.

In the last finding, in the Figure 7, it showed that the children gain self-esteem to do cook and homework independently. They are happy to do those. In the figure 7, the children shows a different attitude. They have high self-esteem. They cook and do the homework by themselves. They raise their confidence to be independent, to be mastery in doing something that they never do before. The different parenting style and language use by the mother influences the changes when the children shows their self-esteem.

Based on the Bad Moms movie, the use speech acts in permissive parenting style is mostly expressive and commissive utterance. Then, the speech acts used in the authoritative 
parenting style is mostly directive utterances. The use of authoritative parenting style reflected in the Bad Moms movie showed the children gain more their self-esteem to be independent children than the use of permissive parenting style. The use of directive utterances in the authoritative parenting style also supports the hearer to do something. It makes the children do the mothers wants, by doing something, the children become independent.

The use of directive utterances based on Georgalidou (2008) and John, Brooks, \& Schriever (2019) research as the secondary data support the primary data about the language use in parenting style toward children' self-esteem. John, Brooks, \& Schriever's (2019) research focused in the use of commissive and directive utterances which gave an impact and emerged a risk in the speaker and hearer action. The result of the research contributed to evaluate causal factors in effective communication and minimize the factors of miscommunication in the maritime domain. The commissive and directive utterances categorized into no risk, residual risk and caused high risk. Georgalidou (2008) studied The Contextual Parameters of Linguistic Choice: Greek Children's Preferences for the Formation of Directive Speech Acts. It investigated the children language use in directive utterance which is used to the teachers or the other students. The children tend to use declarative in directive illocutionary force. Finally, the writers take the conclusion the use of directive utterances based on Georgalidou (2008) and John, Brooks, \& Schriever (2019) research helps the hearer to reduce miscommunication and improve the effective communication. It reflected in the language use in authoritative parenting style which showed the children know what to do and its impact in their self-esteem.

\section{Conclusion}

Based on Bad Moms movie, there are two types of parenting style which applied by Amy. They are permissive and authoritative parenting style. In the beginning of the story, Amy treats her children by using permissive parenting style. It gives impact the children have low self-esteem to do their job independently. Then, Amy changed her parenting style into authoritative. The authoritative parenting style gives the positive effect on children selfesteem. The language use in both of parenting styles is also different. The use of speech acts in permissive parenting style is mostly expressive and commisive utterance. Then, the speech acts used in the authoritative parenting style are mostly directive utterances. The use of authoritative parenting style reflected in the Bad Moms movie showed the children gain more their confidence to be independent children than the use of permissive parenting style. The use of directive utterances in the authoritative parenting style also supports the hearer to reduce miscommunication and improve the effective communication. In this case, the children understand what to do.

\section{Acknowledgment}

The researchers would like to thank to the Magister of English Education of Pascasarjana UMS who help in funding the research. The support means a lot to the reserchers and thank to the ICCOLIC UNS who gave the suggesstions to improve the paper. 


\section{References}

Baumrind, D. (1967). Child care practices anteceding three patterns of preschool behavior. Genetic Psychology Monographs, 75(1), 43-88.

Confucius. (1979). The Analects: Translated vt D.C Lau. London: Penguin.

Creswell, J. W. (2019). Research Design. Pendekatan Kualitatif, Kuantitatif, dan Mixed. Terj. Ahmad Fawaid. Yogyakarta: Pustaka Pelajar.

Farzand, M., Çerkez, Y., \& Çavusoglu, Ç. (2017). Empirical Studies on Parenting Styles: A Trend Analysis. International Journal of Educational Sciences, 19(2-3), 152-158. https://doi.org/10.1080/09751122.2017.1393959

Georgalidou M. (2008). The contextual parameters of linguistic choice: Greek children's preferences for the formation of directive speech acts. Journal of Pragmatics, 40(1), 72-94.

Hesari, N. K. Z., \& Hejazi, E. (2011). The mediating role of self esteem in the relationship between the authoritative parenting style and aggression. Procedia - Social and Behavioral Sciences, 30, pp 1724-1730. https://doi.org/10.1016/j.sbspro.2011.10.333

John, P., Brooks, B., \& Schriever, U. (2019). Speech acts in professional maritime discourse: A pragmatic risk analysis of bridge team communication directives and commissives in full-mission simulation. Journal of Pragmatics, 140, 12-21. https://doi.org/10.1016/j.pragma.2018.11.013

Kochańska, A. (2018). The hurting and healing power of words (and grammatical constructions). A cognitive grammar study of the interactive and interpersonal effects of a directive construction in Polish. Journal of Pragmatics, 134, 1-14.

Kreidler, C. (1998). Introducing English Semantics. Routledge: London.

Nugroho, A. (2019). A Future Teacher Trend: A Sociological Study On Freedom. Humanity and Social Sciences, 7(3), 306-314.

Permatasari, A. I. (2017). A socio-pragmatic analysis of women expressive utterances in bad moms movie. Research Paper.

Putri, M. H. (2017). The Analysis of Gender Stereotypes in Bad Moms. Pioneer, 9(1), 17-23.

Shintya, D. F. (2013). Maslow' S Hierarchy of Needs Manifested By the Main Character in the Forrest Gump the Movie. English Department of Languages and Literature Faculty of Cultural Studies.

Sindy Agusrini. (2017). Representasi Peran Amy Sebagai Ibu Mandiri Dalam Film Bad Moms 2016.

Theresya, J., Latifah, M., \& Hernawati, N. (2018). The Effect of Parenting Style, Self Efficacy, and Self Regulated Learning on Adolescents' Academic Achievement. Journal of Child Development Studies, 3(1), 28. https://doi.org/10.29244/jcds.3.1.28-43 